\title{
Digging deep to open the white black box of snow root phenology
}

Received: 17 October 2013/ Accepted: 27 November 2013/Published online: 11 December 2013

(C) The Ecological Society of Japan 2013

\begin{abstract}
Snow roots are specialized structures recently discovered in the Caucasian alpine snow-bed plant Corydalis conorhiza. They form extensive networks that grow into snow packs against gravity, most probably to gather nitrogen from snow. Here we test the hypothesis that snow roots are true winter organs, i.e., they should already start growth early in winter to lay down the infrastructure for $\mathrm{N}$ capture from snow packs well before their melt-out. This would require winter surface and soil temperatures continuously close to or above freezing. Excavations of snow roots from snow packs in January and May, accompanied by temperature recordings and anatomical observations, supported our hypothesis. These findings complete the annual cycle of snow root phenology. They also emphasize the evolu-
\end{abstract}

\footnotetext{
V. G. Onipchenko

Department of Geobotany, Faculty of Biology, Moscow State University, Moscow 119991, Russia
}

V. G. Onipchenko · A. M. Kipkeev · F. S. Salpagarova Karachaevo-Cherkessian University, Lenina ul. 29, Karachaevsk, Karachaevo-Cherkessian Republic 369200, Russia

V. G. Onipchenko · D. K. Tekeev

Teberda State Reserve, Badukskii 1, Teberda,

Karachaevo-Cherkessian Republic 369210, Russia

M. I. Makarov

Department of General Pedology, Faculty of Soil Science,

Moscow State University, Moscow 119991, Russia

A. D. Kozhevnikova $\cdot$ V. B. Ivanov

Timiryazev Institute of Plant Physiology RAS, Botanicheskaya ul. 35, Moscow 127276, Russia

N. A. Soudzilovskaia · J. H. C. Cornelissen ( $ه)$

Systems Ecology Department of Ecological Science, Faculty of Earth and Life Sciences, VU University, De Boelelaan 1085, 1081 HV Amsterdam, The Netherlands

E-mail: j.h.c.cornelissen@vu.nl

M. J. A. Werger

Department of Plant Ecology and Biodiversity, Faculty of Science, Utrecht University, Utrecht, The Netherlands tionary and ecological significance of these specialized winter organs. Moreover, their likely association with a particular abiotic temperature and snow regime will facilitate the search for snow roots in other species.

Keywords Alpine snow bed · Anatomy - Life history · Nutrient uptake strategy $\cdot$ Snow roots $\cdot$ Winter ecology

\section{Introduction}

Snow roots are amazing specialized structures of alpine plants. They form extensive networks that grow into snow packs against gravity, most probably to gather nutrients from snow. They were discovered recently on Corydalis conorhiza Ledeb. (Papaveraceae) in melting snow in an alpine snow bed community in the North-west Caucasus, southern Russia (Onipchenko et al. 2009; Fig. 1a, b). Nitrogen uptake from snow by C. conorhiza, and its subsequent translocation to the leaves, was demonstrated in an experiment with ${ }^{15} \mathrm{~N}$ addition to snow packs (Onipchenko et al. 2009). This 'special' plant $\mathrm{N}$ acquisition strategy complements the list of other such strategies including symbioses with mycorrhizal fungi or $\mathrm{N}_{2}$-fixing bacteria, parasitism and carnivory (cf. Lambers et al. 2008). We know that the $\mathrm{N}$ acquisitive strategy of snow roots is associated with their extremely high specific root length and their special anatomy, with small diameter and lack of structural deposits in the epidermis. However, this knowledge is based only on snow root sampling at the end of snow melt in July (Onipchenko et al. 2009; Fig. 1a). To fully appreciate the evolutionary advancement that snow roots represent, we need to consider their whole annual cycle including their winter phenology. This will help us uncover whether (1) snow roots are merely an ephemeral spring feature, developing only during melt-out of the snow pack; or (2) they are a true winter organ, developing and persisting inside the snow pack throughout the alpine winter. As snow roots grow upward from the lower parts of the belowground tubers of C. conorhiza, they would be unlikely 

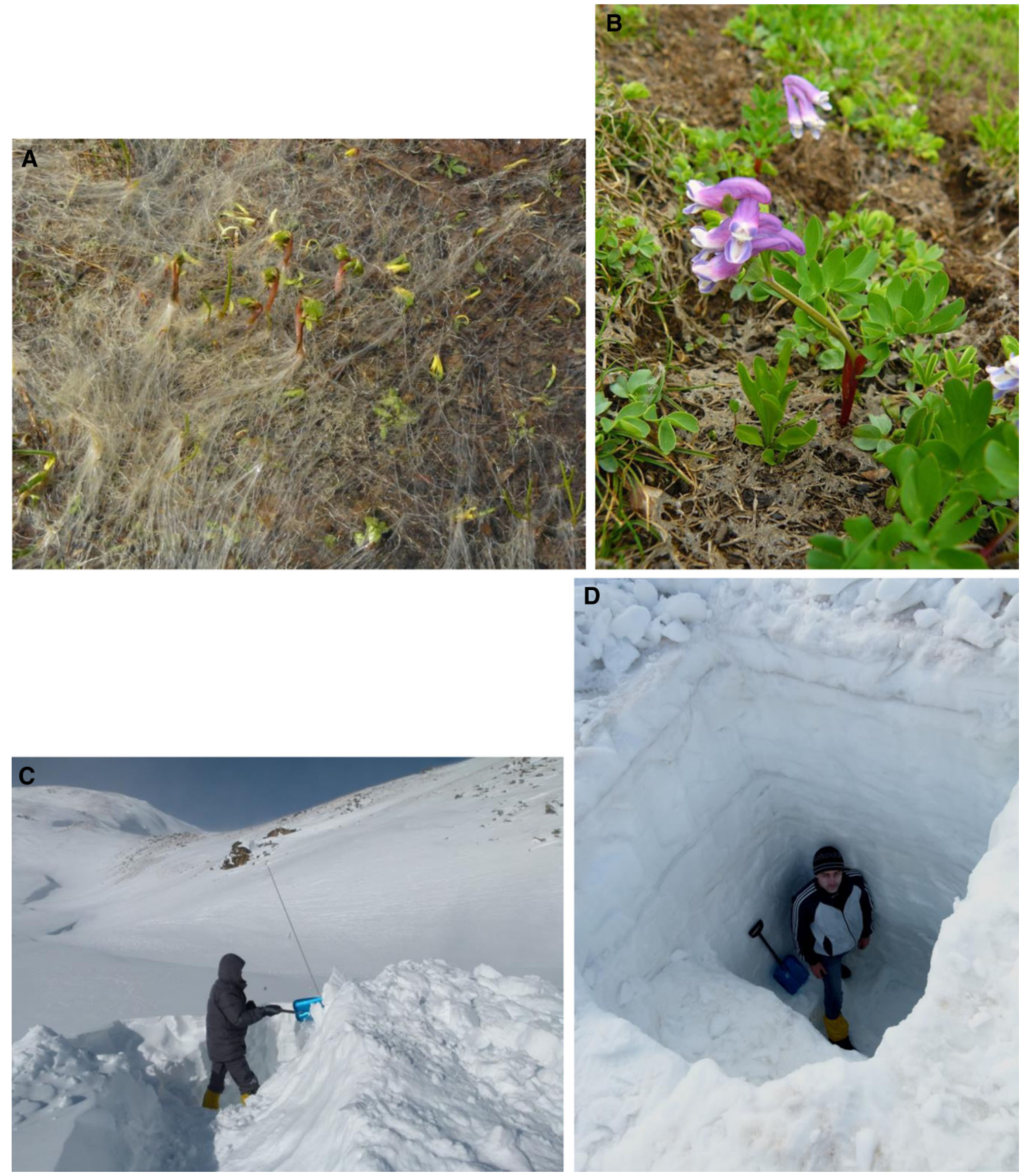

Fig. 1 Annual cycle of Corydalis conorhiza snow roots in the field. a Snow roots just after snow melt, with new shoots pushing through in July. b Flowering shoots and remnants of the dead and partially decayed snow roots on the soil surface, in August.

to start developing in early winter if the soil were deeply frozen then. However, in alpine areas of the temperate zone, temperatures in the lower part of the snow pack tend to be near $0{ }^{\circ} \mathrm{C}$ when the snow depth exceeds $\sim 0.5 \mathrm{~m}$ (Brooks et al. 1997; Pomeroy and Brun 2001). In alpine Caucasian snow beds, the snow depth does exceed $0.5 \mathrm{~m}$ and soil temperatures are close to zero throughout the winter (see below). Accordingly, we hypothesized that snow roots can grow throughout the whole winter period. To test this hypothesis, we overcame the logistic challenges c Excavation of snow roots from snow pack in previously marked plot on 8 January 2013, when snow depth was $2.2 \mathrm{~m}$. d Excavation of snow roots from adjacent spot in the same snow pack on 9 May 2013, when snow depth was 3.5 m. Photos by V.G. Onipchenko

of winter access to the Caucasian snow beds that host $C$. conorhiza and carried out a study to unveil the secrets of winter phenology and anatomy of snow roots.

\section{Methods}

The study was carried out in the alpine vegetation belt on Mt. Malaya Khatipara in Teberda Nature Reserve, NW Caucasus, Russia $\left(43^{\circ} 27^{\prime} \mathrm{N}, 41^{\circ} 42^{\prime} \mathrm{E}\right.$; altitude 

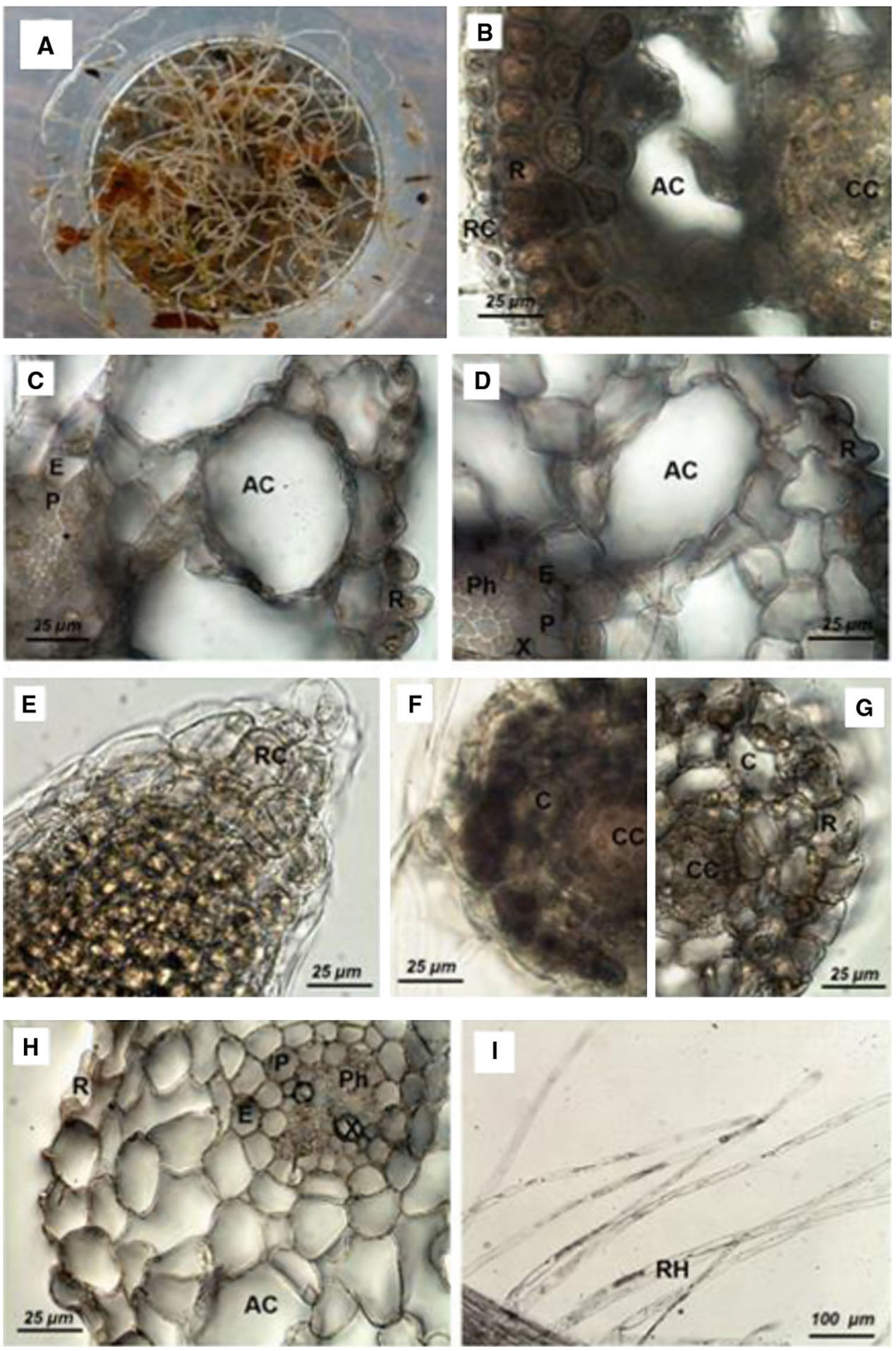

Fig. 2 Morphology and anatomy of snow roots of Corydalis conorhiza. a Snow root collection using a sieve, January 2013. bd Sections of the snow roots sampled in January 2013; e-i Sections of snow roots sampled in May 2013; b, f Cross-sections of the meristem zone (with aerenchymatous cortex in b); $\mathbf{c}, \mathbf{d}, \mathbf{h}$ Mature

2,800 m). Details about macroclimate, vegetation composition and soil characteristics of the snow bed community under investigation are given in Onipchenko (2004) and Onipchenko et al. (2009). snow root tissues; e Root tip; $\mathbf{g}$ Transition from meristem zone to elongation zone; i Root hairs protruding from a snow root section. $A C$ Aerenchymatous cortex, $C$ cortex, $C C$ central cylinder, $E$ endodermis, $P$ pericycle, $P h$ phloem, $R$ rhizodermis, $R C$ root cap, $R H$ root hairs, $X$ xylem. Photos by the authors

We monitored the temperatures at soil surface and at $10 \mathrm{~cm}$ depth in the soil in two of the snow bed plots with C. conorhiza studied here for snow roots, using iButton DS 1921Z sensors (Dallas Semiconductor, Dallas, TX; 
precision $\pm 0.5^{\circ} \mathrm{C}$ ), year-round from the winter of $2006 / 2007$ through the winter of $2012 / 2013$.

A site with high abundance of $C$. conorhiza was marked with a 4-m mast in the autumn of 2012. We excavated the snow pack in this spot on 8 January 2013, when the snow was $2.2 \mathrm{~m}$ deep (Fig. 1c). A snow sample of the lowermost snow layer (snow lying directly on the soil surface) with a surface area of $0.5 \times 0.5 \mathrm{~m}$ and a thickness of 50-70 mm was sealed into plastic bags. The total amount of snow $(13 \mathrm{~L})$ in this sample was equivalent to $6.5 \mathrm{~L}$ water. The pit was subsequently filled in again with the excavated snow. The sample was kept in the laboratory $\left(+20^{\circ} \mathrm{C}\right)$ for 1 day to melt the snow. The water was subsequently filtered using a thin metal sieve (mesh size $0.25 \times 0.25 \mathrm{~mm}$ ). Roots were collected from the sieve (Fig. 2a) and fixed in $70 \%$ ethanol for further analysis.

A second snow excavation was carried out on 9 May 2013 in the same area, several meters away from the January pit in order to avoid any snow digging artefacts. At that moment snow depth there was $3.5 \mathrm{~m}$ and the snow was much denser than in January (Fig. 1d). We laid out three subplots in the vertical walls of the snow pit, i.e., $\sim 1 \mathrm{~m}$ apart. In each subplot, we took three snow samples at $0-0.25,0.25-0.50$ and $0.50-0.75 \mathrm{~m}$ above soil level, respectively. Each sample comprised about 2-3 L snow. We extracted and fixed the roots in these snow samples in the same way as in January. All snow root samples were taken to the Timiryazev Institute of Plant Physiology RAS, Moscow, for anatomical observations and photography as described in Onipchenko et al. (2009).

\section{Results}

Our monitoring of the soil surface temperatures during the entire period from winter 2006/2007 through winter $2012 / 2013$ showed that the winter of $2012 / 2013$ was largely representative of the longer-term annual temperature patterns (Fig. 3a, b). Also, the temperature profiles at $0.10 \mathrm{~m}$ soil depth were largely similar to those at the surface, without any subzero temperatures (data not shown). These temperature data help to put the annual cycle of snow roots into their environmental context. During the summer (early/mid July-August) high temperatures indicate the growing season. After complete melt-out, the new $C$. conorhiza shoots push
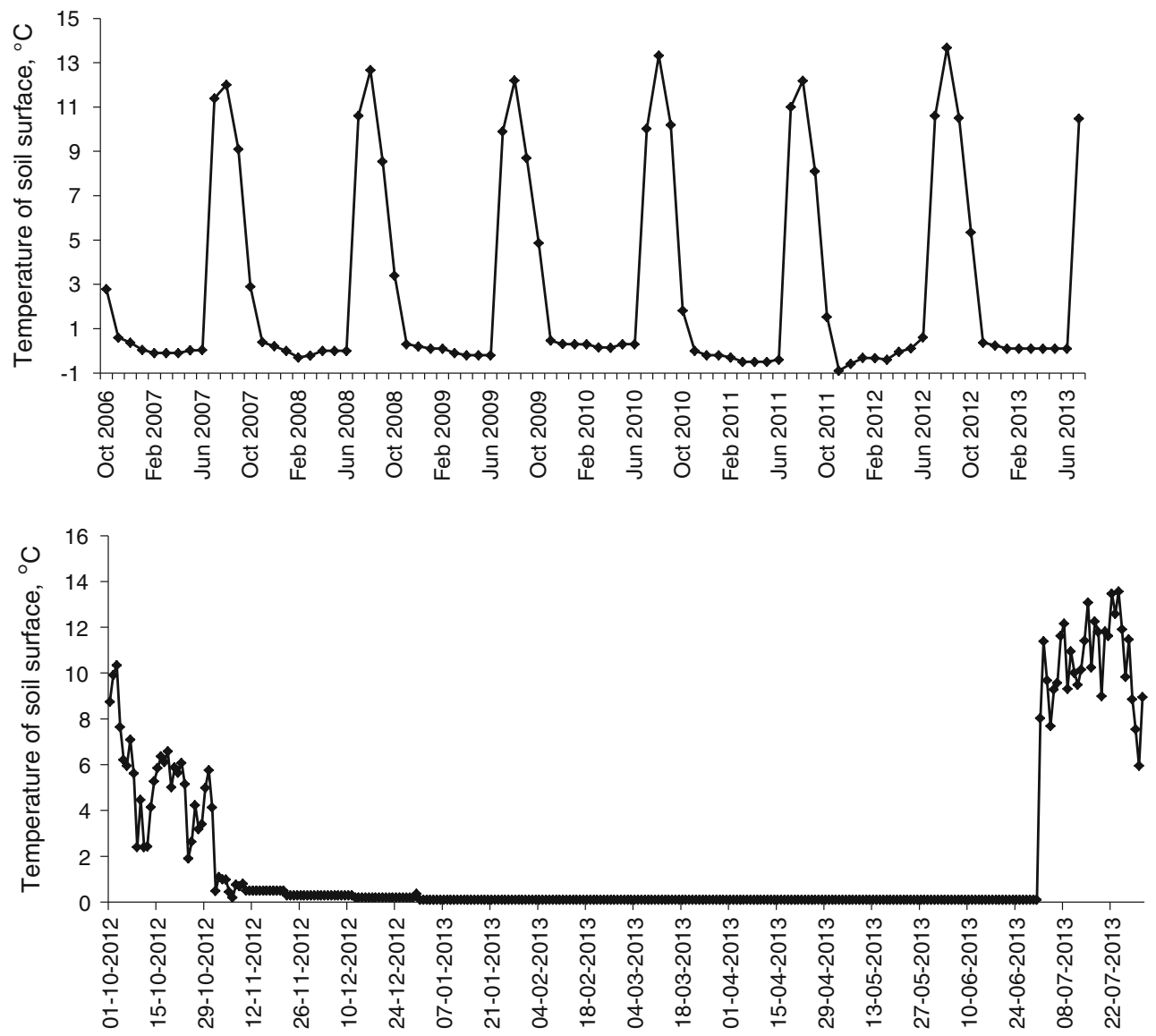

Fig. 3 Soil surface temperature profiles in the snow bed areas from which snow roots were sampled. a Mean monthly temperatures over the period 2006-2013. b Daily mean temperatures over the period October 2012-July 2013 
Table 1 Traits of snow roots collected from the snowpack in January and May 2013

\begin{tabular}{lllll}
\hline Sample $^{\mathrm{a}}$ & $\begin{array}{l}\text { Total root } \\
\text { length }(\mathrm{m})\end{array}$ & $\begin{array}{l}\text { Specific root } \\
\text { length }\left(\mathrm{m} \mathrm{g} \mathrm{g}^{-1}\right)\end{array}$ & $\begin{array}{l}\text { Snow root } \\
\text { density }\left(\mathrm{mm} \mathrm{L}^{-1}\right)\end{array}$ & $\begin{array}{l}\text { Mean root } \\
\text { diameter }(\mu \mathrm{m})\end{array}$ \\
\hline January & 3.32 & c. 350 & c. 250 & $349 \pm 8$ \\
May & 7.25 & $1,040 \pm 11$ & $1,498 \pm 663$ & $189 \pm 9$ \\
\hline
\end{tabular}

${ }^{\mathrm{a}}$ Data for January are based on one sample, for May on three samples

through their own snow roots, which then form a dense white 'blanket' on the soil surface (Fig. 1a). In August, during flowering, these snow roots have already died and partly decomposed (Fig. 1b). In autumn (September to mid/late October) 2012, before the establishment of the winter snow cover, the snow bed soil was not frozen (Fig. 3b). At that time there was no visible evidence of previous year's snow roots anymore (authors' observations). In 2012, the snow cover began to build up on 1 November and the soil temperature became stable on 8 November, when it ranged from +0.5 to $+1( \pm 1.0){ }^{\circ} \mathrm{C}$. It then decreased very slowly from November to snow melt-out in early July by about $1{ }^{\circ} \mathrm{C}$.

The January sample yielded a significant amount of snow roots (Fig. 2a; Table 1). These were the relatively thick, sturdy basal parts emerging from the lower parts of the tubers (Fig. 2a-d). Their total length was $3.32 \mathrm{~m}$, their specific root length was about $350 \mathrm{~m} \mathrm{~g}^{-1}$. Mean snow root diameter was $0.349 \pm 0.008 \mathrm{~mm}$ (mean \pm $\mathrm{SE}, n=56$ ). Anatomical slides showed the following main features. The cortex was aerenchymatous (Fig. 2bd) and the aerenchyma started to develop already in the meristem zone of the root (Fig. 2b). Cortical cells often formed thin "strips", while the cavities were very large. There were often five to eight cortical rows and the central cylinder was also wider than in May roots (Fig. 2b-d, cf. Fig. 2f-h). Root hairs were short and rare. Casparian strips in the endodermis were more pronounced in January snow roots (Fig. 2d) than in May roots (cf. Fig. 2h). At ca. $250 \mathrm{~mm}$ per liter of snow, root density was not yet high in the snow layer up to 50-70 $\mathrm{mm}$ from the soil surface.

In the May snow samples (Fig. 2e-i; Table 1), there were practically no snow roots above $0.25 \mathrm{~m}$ above soil level ( $<10 \mathrm{~mm}$ per liter snow), none at $0.50-0.75 \mathrm{~m}$. In contrast, there were a lot of snow roots in the snow layer up to $0.25 \mathrm{~m}$ above the soil, with densities at $1,498 \pm 663 \mathrm{~mm}$ per liter snow. At $0.189 \pm 0.009 \mathrm{~mm}$ $(n=36)$ diameter (Fig. 2e-h; Table 1) the snow roots were about half as thin as those in January and more branched. The meristem contained no aerenchyma (Fig. 2f, g). In mature May snow roots (Fig. 2h) the aerenchyma was less developed than in January roots (cf. Fig. 2c, d). There were often three to five cortical rows. Root hairs in snow roots in May (Fig. 2i) were long and more densely located over the root surface than in January roots. Specific root length was three times as high as in January $\left(1,040 \pm 11 \mathrm{~m} \mathrm{~g}^{-1}\right.$, $n=3)$.

\section{Discussion}

We had to dig deep into a Caucasian alpine snow pack to open the 'white black box' of snow root phenology of C. conorhiza. Our results demonstrate that we opened this box successfully, i.e., the winter snow pack. This provided us with convincing empirical evidence in support of our hypothesis: snow roots of $C$. conorhiza start to develop already early in winter and persist in the snow pack at up to $0.25 \mathrm{~m}$ height above the soil surface until complete melt-out in July. They can do so because soil temperatures remain close to $0{ }^{\circ} \mathrm{C}$ throughout winter and spring.

Earlier studies revealed that roots of alpine plants can grow at a minimum temperature of about $-0.5^{\circ} \mathrm{C}$, but that their elongation rates at low temperatures $\left(<5{ }^{\circ} \mathrm{C}\right)$ are very low. For this temperature interval, those rates would amount to $0.2-2.5 \mathrm{~mm}$ per day (Bliss 1956; Körner 2003). Our observations showed that soil (surface) temperatures in our snow beds do allow root growth throughout winter and that $C$. conorhiza actually had been growing roots since before the beginning of January. These roots were not shorter than $50 \mathrm{~mm}$ and, thus, at a growth rate of 1-2 $\mathrm{mm}$ per day they must have started to develop in the snow no later than early- to mid-December. Clearly, even though carbon investments into these thin snow roots per unit length must be small, as apparent from their aerenchymatous anatomy and very high specific root length (see also Onipchenko et al. 2009), they develop during most of the winter and spring. Thus they have a life span of several months.

Our findings bring us a big step closer to gauging the full evolutionary and ecological significance of snow roots suggested earlier (Onipchenko et al. 2009). We have demonstrated that snow roots are not merely adventitious spring roots that elongate fast during snow melt to benefit from the nutrients in snow melt water (and possibly partly from soil nutrients dissolved therein). Instead we can now conclude with confidence that snow roots are true specialized winter organs associated with snow packs throughout the Caucasian winter from as early as January or perhaps even December. Already by May, i.e., well before snow melt, they have expanded into an extensive network of long and thin, branched roots with abundant root hairs and extremely high specific root length, features that are all consistent with their ' $\mathrm{N}$ foraging' function (Onipchenko et al. 2009). We still do not know how much nitrogen they take up and translocate during the winter period 
(January-May). Perhaps this could be tested by labeling snow beds with ${ }^{15} \mathrm{~N}$ during winter; or by growing the plants in a climatized greenhouse with artificial snow of different $\mathrm{N}$ concentrations, and subsequently testing the plants' growth performance. However, even if $\mathrm{N}$ uptake during spring snow melt (Onipchenko et al. 2009) were more than that in winter itself (something still awaiting empirical testing), we have revealed that the snow root infrastructure to support this uptake is already fully in place during peak snow cover in May, after a growing period that already started early in winter.

The biggest next challenge is now to check whether the Tree of Life features other plant species with snow roots, in closely related or distant taxa, in the Caucasus or in distant regions elsewhere in the world. Now that we have shown the likely association of snow root phenology with temperatures around or (just) above freezing, this search can be narrowed down somewhat by first checking out snow bed areas with similar abiotic regimes. Given the hidden nature of white snow roots below a white cover, and their fast death and disappearance after snow melt-out, it is not unthinkable that they might even still be found in snow bed communities visited by biologists or naturalists previously. It is also likely that the apparent dependence of $C$. conorhiza, and any yet undiscovered snow root species, on deep snow packs with a particular soil temperature regime makes such alpine specialists particularly vulnerable to winter warming.
Acknowledgments This work was supported by RFBF No. 11-0401215 to V.G.O. and M.I.M. and NWO grant 047.018 .003 to J.H.C.C. We also thank Dr. Makoto Kobayashi and the Ecological Society of Japan for organising the special symposium on Winter climate change effects at the 2013 Annual Meeting in Shizuoka; and to Professor N. Kachi and Ecological Research for inviting and funding J.H.C.C. to present snow root ecology there. We thank Richard van Logtestijn for text suggestions for the manuscript.

\section{References}

Bliss LC (1956) A comparison of plant development in microenvironments of arctic and alpine tundras. Ecol Monogr 26:303-337

Brooks PD, Schmidt SK, Williams MW (1997) Winter production of $\mathrm{CO}_{2}$ and $\mathrm{N}_{2} \mathrm{O}$ from alpine tundra: environmental controls and relationship to inter-system $\mathrm{C}$ and $\mathrm{N}$ fluxes. Oecologia 110:403-413

Körner C (2003) Alpine plant life: functional plant ecology of high mountain ecosystems, 2nd edn. Springer, Berlin

Lambers H, Chapin FS, Pons TL (2008) Plant physiological ecology, 2nd edn. Springer, New York

Onipchenko VG (ed) (2004) Alpine ecosystems in the Northwest Caucasus. Kluwer, Dordrecht

Onipchenko VG, Makarov MI, van Logtestijn RSP, Ivanov VB, Akhmetzhanova AA, Tekeev DK, Ermak AA, Salpagarova FS, Kozhevnikova AD, Cornelissen JHC (2009) New nitrogen uptake strategy: specialized snow roots. Ecol Lett 12:758-764

Pomeroy JW, Brun E (2001) Physical properties of snow. Pages 45-126. In: Jones HG (ed) Snow ecology. Cambridge University Press, Cambridge, p 26 